\title{
Purification of two isofunctional hydrolases (EC 3.7.1.8) in the degradative pathway for dibenzofuran in Sphingomonas sp. strain RW1
}

\author{
Patricia V. Bünz, ${ }^{1,2}$ Rocco Falchetto ${ }^{3} \&$ Alasdair M. Cook ${ }^{1 *}$ \\ Institutes of ${ }^{1}$ Microbiology and ${ }^{3}$ Biochemistry, Swiss Federal Institute of Technology, ETH-Zentrum, \\ CH-8092 Zürich, Switzerland; ${ }^{2}$ Institut für Allgemeine Botanik, Abteilung Mikrobiologie, Universität \\ Hamburg, D-22609 Hamburg, Germany (* requests for offprints)
}

Key words: dibenzofuran, metabolism of dibenzofuran pathway intermediates, 2,2',3-trihydroxybiphenyl, meta cleavage enzymes, hydrolysis of a C-C bond (EC 3.7.1.8), HOHPDA hydrolases (EC 3.7.1.8)

\begin{abstract}
Sphingomonas sp. strain RW1, when grown in salicylate-salts medium, synthesized the enzymes for the degradation of dibenzofuran. The reaction subsequent to meta cleavage of the first benzene ring was found to be catalyzed by two isofunctional hydrolases, $\mathrm{H} 1$ and $\mathrm{H} 2$, which were purified by chromatography on anion exchange, hydrophobic interaction and gel filtration media. Each enzyme was able to hydrolyze 2-hydroxy-6oxo-6-(2-hydroxyphenyl)hexa-2,4-dienoate and 2-hydroxy-6-oxo-6-phenylhexa-2,4-dienoate to produce salicylate and benzoate, respectively. SDS/PAGE of each purified enzyme showed a single band of $M_{r} 31000(\mathrm{H} 1)$ or $29000(\mathrm{H} 2)$. The N-terminal amino acid sequences of the two proteins showed $50 \%$ homology.
\end{abstract}

Abbreviations: DHB - 2,3-dihydroxybiphenyl, DSM - German Culture Collection (Braunschweig), FPLCprotein liquid chromatograph(y), HOHPDA - 2-hydroxy-6-oxo-6-(2-hydroxyphenyl)hexa-2,4-dienoate, HOPDA - 2-hydroxy-6-oxo-6-phenylhexa-2,4-dienoate, THB - 2,2',3-trihydroxybiphenyl

\section{Introduction}

Degradative pathways of dibenzofuran (Engesser et al. 1989; Fortnagel et al. 1989, 1990; Strubel et al. 1991; Wilkes et al. 1992; Wittich et al. 1992) and biphenyl (Higson 1992) have been elucidated (Fig. 1).

Whereas there is an increasing understanding of multi-component dioxygenases (Correll et al. 1992; Harayama et al. 1992; Mason \& Cammack 1992) and meta-cleavage enzymes (Lipscomb et al. 1988; Harayama et al. 1992) much less is known about the hydrolytic cleavage of C-C bonds (EC 3.7.1.-) in the degradation of aromatic compounds. Three 2-hydroxy-6-oxo-2,4-heptadienoate hydrolases (EC
3.7.1.9; Bayly \& Di Berardino 1978; Duggleby \& Williams 1986) from strains of Pseudomonas putida and a HOPDA-hydrolyzing enzyme from the biphenyl-degrading Pseudomonas cruciviae strain S93B1 (EC 3.7.1.8; Omori et al. 1986a) have been reported. In this paper we describe the purification of two isofunctional enzymes (EC 3.7.1.8) from Sphingomonas sp. strain RW1, an organism which is able to utilize dibenzofuran and dibenzo- $p$-dioxin as sole source of carbon and energy for growth (Wittich et al. 1992). 


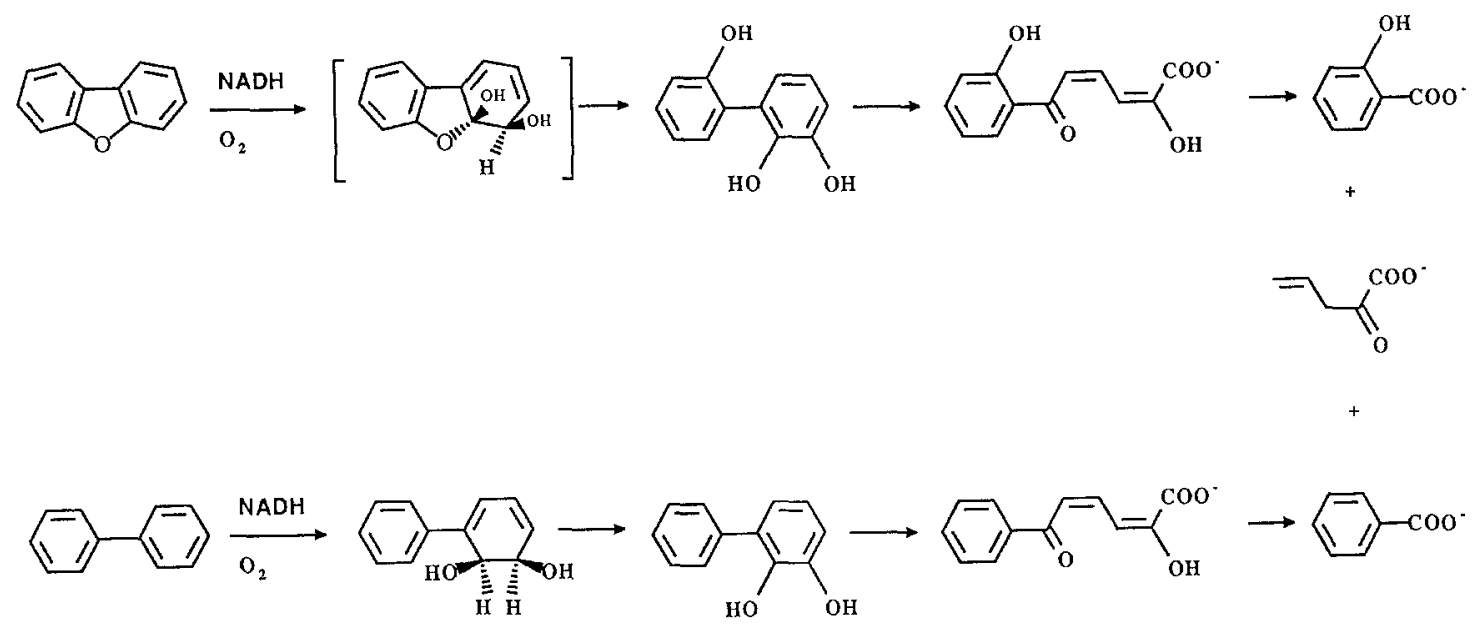

Fig. 1. Initial reactions in selected degradative pathways of dibenzofuran and biphenyl. The initial reaction in each case is catalyzed by a multi-component dioxygenase (Bünz \& Cook 1993; Haddock et al. 1993). Biphenyl 2,3-dioxygenase yields a stable cis-diol which is converted to the catechol (2,3-dihydroxybiphenyl) by a dehydrogenase (Gibson et al. 1973; Higson 1992). Dibenzofuran-4,4a-dioxygenase forms an unstable hemiacetal which decays spontaneously to the catechol $\left(2,2^{\prime}, 3\right.$-trihydroxybiphenyl). The catechol is subject to meta ring cleavage yielding the chemically reactive intermediates 2-hydroxy-6-oxo-6-phenylhexa-2,4-dienoate (HOPDA, from biphenyl) and 2-hydroxy-6-oxo-6-(2-hydroxyphenyl)hexa-2,4-dienoate (HOHPDA, from dibenzofuran); the depiction of the cis,cis isomer is purely formal, given the rapid spontaneous keto-enol tautomerism (Omori et al. 1986a,b; Whitman et al.1991). There follows a hydrolytic step which converts HOPDA (HOHPDA) to benzoate (salicylate) and 2-oxopentenoate (Omori et al. 1986a; Strubel et al. 1991). Whereas this is the only characterized degradative pathway for dibenzofuran, alternative fates for (chloro)biphenyl are known, e.g. the reduction of HOPDA (Omori et al. 1986b; Ahmad et al. 1991; Higson 1992).

\section{Materials and methods}

\section{Materials}

Dibenzofuran (Aldrich, Milwaukee, WI, USA), sodium salicylate (Fluka, Buchs, Switzerland), 2,3-dihydroxybiphenyl (Wako Chemicals, Neuss, Germany), DNase I (Boehringer Mannheim GmbH, Germany) and aprotinin (Sigma, St. Louis, MO, USA) were from commercial sources. THB was kindly provided by Dr. H. Harms (cf. Fortnagel et al. 1990). HOHPDA (HOPDA) was prepared in 10$\mathrm{ml}$ reaction mixtures from $0.5 \mathrm{mmol}$ THB $(1 \mathrm{mmol}$ 2,3-dihydroxybiphenyl) by oxygenation with $0.2 \mathrm{mg}$ of partially purified THB 1,2-dioxygenase from Sphingomonas sp. strain RW1 (see below) in $50 \mathrm{mM}$ potassium phosphate buffer, $\mathrm{pH}$ 7.4. The proteins were removed by membrane filtration (Centriprep-10). The concentration of the yellow product was determined photometrically; a molar absorption coefficient of 130001 (mol.cm) $^{-1}$ at $432 \mathrm{~nm}$ was used (Omori et al. 1986a). HOPDA was stable at $4^{\circ} \mathrm{C}$ for one week, whereas HOHPDA showed a loss of colour after $15 \mathrm{~min}$. The FPLC co- lumns DEAE-Sepharose CL-6B (26 by $145 \mathrm{~mm}$ ), and commercially-packed Mono Q HR (16 by $100 \mathrm{~mm}$ ), Phenyl Superose HR ( 5 by $50 \mathrm{~mm}$ ) and Superose 12 or 6 HR (10 by $300 \mathrm{~mm}$ ) were from Pharmacia (Uppsala, Sweden) which also provided Blue Dextran 2000, molecular weight standards for gel filtration and PD-10 columns of Sephadex G-25. Molecular weight standards for PAGE, reagents for SDS/PAGE and premade gradient PAGE gels (4 to $20 \%$ ) were from BIO-RAD, Richmond, CA, USA. Membrane filtration units were from Amicon (Danvers, MA, USA). The sources of other chemicals are in Locher et al. (1991).

\section{Analytical methods}

Spectrophotometric determinations were done with a Uvikon 820 (Kontron, Zürich, Switzerland). Protein concentration was assayed by the method of Bradford (1976) with bovine serum albumin as the standard. Reversed-phase HPLC was done at room temperature with $50 \%(\mathrm{v} / \mathrm{v})$ methanol in $10 \mathrm{mM}$ potassium phosphate buffer, $\mathrm{pH} 2.2$, as the 
mobile phase (Locher et al. 1989). FPLC was done with apparatus from Pharmacia (the DEAE column at $4^{\circ} \mathrm{C}$ ) or with HPLC apparatus at room temperature (Locher et al. 1991). The mobile phase was sparged with oxygen-free helium and fractions were collected on ice under a stream of oxygen-free $\mathrm{N}_{2}$.

The progress of protein purifications and the $M_{r}$ of proteins under denaturing conditions was determined by SDS/PAGE; gels were routinely stained with Coomassie brilliant blue and occasionally with silver (Laemmli 1970; Merril et al. 1983; Locher et al. 1991). The estimation of $M_{r}$ under native conditions was done routinely by gel filtration chromatography with a Superose column at flow rates of 0.3 to $0.6 \mathrm{ml} / \mathrm{min}$. The eluent was $50 \mathrm{mM}$ Tris sulphate, pH 7.5, containing $150 \mathrm{mM} \mathrm{Na}_{2} \mathrm{SO}_{4}$. The molecular weight standards were ferritin (440 000), aldolase (158 000), bovine serum albumin (67 000), cytochrome c (12 500) and aprotinin (6 800). On occasion, gradient gels under native conditions were used. The broad range standard from BIO-RAD was used for molecular weight determination.

The N-terminal amino acid sequence of a purified and desalted enzyme, or of a blotted protein, was determined by automated Edman degradation (Locher et al. 1991).

HOHPDA-hydrolase was routinely assayed at $25^{\circ} \mathrm{C}$ as the decrease in absorbance of the substrate at $432 \mathrm{~nm}$ (Omori et al. 1986a). The reaction mixture $(1.0 \mathrm{ml})$ contained $37.5 \mu$ mole of potassium phosphate buffer, $\mathrm{pH} 7.4,0.05$ to $1 \mathrm{mg}$ of protein and 50 nmole of HOPDA (or HOHPDA), with which the reaction was started. The hydrolases were sometimes determined by HPLC as benzoate (salicylate) formed from HOPDA (HOHPDA).

THB-1,2-dioxygenase was detected as the formation of HOHPDA from THB; the enzyme was routinely assayed at $432 \mathrm{~nm}$ as formation of HOPDA from 2,3-dihydroxybiphenyl, using a modified method of Ishigooka et al. (1986) without ferrous sulfate. Alternatively, oxygen uptake was determined in a Clarke-type oxygen electrode with a thermostated $\left(30^{\circ} \mathrm{C}\right) 1-\mathrm{ml}$ reaction vessel (Rank Bros., Bottisham, Cambs., UK). The reaction mixture $(1.0 \mathrm{ml})$ contained $49 \mu$ mole of potassium phosphate buffer, $\mathrm{pH} 7.4,5$ to $200 \mu \mathrm{g}$ of protein and
300 nmole of 2,3-dihydroxybiphenyl (dissolved in acetone) with which the reaction was started.

Catechol-2,3-dioxygenase (EC 1.13.11.2) was assayed as production of 2-hydroxymuconate semialdehyde from catechol (Bird \& Cain 1974).

Organism, growth conditions and preparation of cell-free extract

Sphingomonas sp. strain RW1 (DSM 6014) was stored at $4^{\circ} \mathrm{C}$ on slants of dibenzofuran-salts medium, from which 25 -ml precultures (in 100-ml Erlenmeyer flasks) containing $5 \mathrm{mM}$ salicylate-salts medium [the salts medium of Fortnagel et al. (1990) supplemented with trace elements $(5 \mathrm{ml} / \mathrm{l}$; Drews 1983)] were inoculated. Cultures were grown at $30^{\circ} \mathrm{C}$ on an orbital shaker and cultures in the midexponential phase of growth were used to inoculate $(1.5 \% \mathrm{v} / \mathrm{v})$ the main cultures ( $1.5 \mathrm{l}$ in $5-1$ Erlenmeyer flasks). The main culture was grown for $18 \mathrm{~h}$, when cells were harvested by centrifugation $(5000 \mathrm{~g}, 20$ $\min , 4^{\circ} \mathrm{C}$ ), washed twice in chilled $50 \mathrm{mM}$ Tris- $\mathrm{HCl}$ buffer, $\mathrm{pH} 7.5,\left(10000 \mathrm{~g}, 15 \mathrm{~min}, 4^{\circ} \mathrm{C}\right)$ and stored at $-20^{\circ} \mathrm{C}$.

Frozen cells $(20 \mathrm{~g})$ were suspended $(1 \mathrm{~g} / \mathrm{ml})$ in $50 \mathrm{mM}$ Tris- $\mathrm{HCl}, \mathrm{pH} 7.5$, containing 1 mM DTT. After addition of $0.2 \mathrm{mg} / \mathrm{ml}$ DNase and PMSF to $0.1 \mathrm{mM}$, cells were disrupted by three passages through a chilled French press (130 MPa). Undisrupted cells and other particulate matter were removed by centrifugation $\left(20000 \mathrm{~g}, 30 \mathrm{~min}, 4^{\circ} \mathrm{C}\right)$ and ultracentrifugation $\left(150000 \mathrm{~g}, 60 \mathrm{~min}, 4^{\circ} \mathrm{C}\right.$ ), and cell extract was used immediately. Fractionated proteins were routinely frozen at $-20^{\circ} \mathrm{C}$.

\section{Results}

\section{Purification of two isofunctional HOHPDA} hydrolases

HOHPDA hydrolase was initially detected as the enzyme-catalyzed disappearance of HOHPDA, whereby substrate disappearance was followed photometrically and salicylate formation was detected by HPLC. When isofunctional enzymes were 
Table 1. Buffer systems, all $\mathrm{pH} 7.5$, with $1 \mathrm{mM}$ DTT, used as mobile phases in FPLC.

\begin{tabular}{|c|c|c|}
\hline Column & Buffer A & Buffer B \\
\hline DEAE & A1: $50 \mathrm{mM}$ Tris-HCl & B1: $0.8 \mathrm{M}$ Tris- $\mathrm{HCl}$ \\
\hline Mono Q & A2: $20 \mathrm{mM}$ Tris-SO & $\mathrm{B} 2: \mathrm{A} 2+1 \mathrm{M} \mathrm{Na}_{2} \mathrm{SO}_{4}$ \\
\hline Phenyl Superose & $\mathrm{A} 3: \mathrm{A} 2+0.8 \mathrm{M}\left(\mathrm{NH}_{4}\right)_{2} \mathrm{SO}_{4}$ & B3: A2 \\
\hline Superose & A4: $50 \mathrm{mM}$ Tris- $\mathrm{SO}_{4}+150 \mathrm{mM} \mathrm{Na}_{2} \mathrm{SO}_{4}$ & none \\
\hline
\end{tabular}

detected, it was observed that both HOHPDA and HOPDA were substrates for each enzyme. HOHPDA was much less stable than HOPDA, and HOPDA was prepared from a commercially-available substrate, so each enzyme was routinely assayed with HOPDA as the substrate.

Cell-free extract (about $500 \mathrm{mg}$ of protein in $15 \mathrm{ml}$ buffer A1; Table 1) was applied to a DEAEcolumn equilibrated with buffer $\mathrm{A} 1$ at a flow rate of $2.5 \mathrm{ml} / \mathrm{min}$, and $7-\mathrm{ml}$ fractions were collected. The flow of buffer A1 was maintained for 60 min when a linear gradient to $100 \%$ buffer B1 in 120 min was started. Hydrolase activity was detected in a nonresolved double peak between fractions 42 and 49 , about 450 to $550 \mathrm{mM}$ Tris- $\mathrm{HCl}$ (not shown). Fractions 43 to 48 were pooled and concentrated by membrane filtration.

Proteins from the DEAE column were separated on a Mono Q column (Fig. 2). Two HOHPDA hydrolases were clearly separated as sharp peaks of activity and they were designated $\mathrm{H} 1$ and $\mathrm{H} 2$. Hydrolase $\mathrm{H} 1$ eluted at about $20 \mathrm{mM} \mathrm{Na}_{2} \mathrm{SO}_{4}$ and fractions 28 to 31 were pooled and concentrated for further purification. Hydrolase $\mathrm{H} 2$ eluted at about $65 \mathrm{mM} \mathrm{Na}_{2} \mathrm{SO}_{4}$ and fractions 46 to 49 were pooled and concentrated.

Hydrolase $\mathrm{H} 1$ from the Mono $\mathrm{Q}$ column was brought to $0.8 \mathrm{M}\left(\mathrm{NH}_{4}\right)_{2} \mathrm{SO}_{4}$ by addition of $3 \mathrm{M}$ $\left(\mathrm{NH}_{4}\right)_{2} \mathrm{SO}_{4}$, the $\mathrm{pH}$ was adjusted to 7.5 with $3 \mathrm{M}$ $\mathrm{KOH}$ and the protein applied to a Phenyl Superose column equilibrated with buffer A3; fractions of $0.5 \mathrm{ml}$ were collected. After $10 \mathrm{~min}$ at a flow rate of $0.5 \mathrm{ml} / \mathrm{min}$, the concentration of $\left(\mathrm{NH}_{4}\right)_{2} \mathrm{SO}_{4}$ was decreased to $0 \mathrm{M}$ over $40 \mathrm{~min}$. Active fractions eluted at about $210 \mathrm{mM}\left(\mathrm{NH}_{4}\right)_{2} \mathrm{SO}_{4}$ with the major protein peak observed and were concentrated (not shown).

Hydrolase $\mathrm{H} 2$ precipitated on the addition of $\left(\mathrm{NH}_{4}\right)_{2} \mathrm{SO}_{4}$ in the range of 0.4 to $1.7 \mathrm{M}$. The supernatant fluid was discarded, the precipitate was dissolved in buffer $\mathrm{A} 2$ containing $0.3 \mathrm{M}-\left(\mathrm{NH}_{4}\right)_{2} \mathrm{SO}_{4}$,

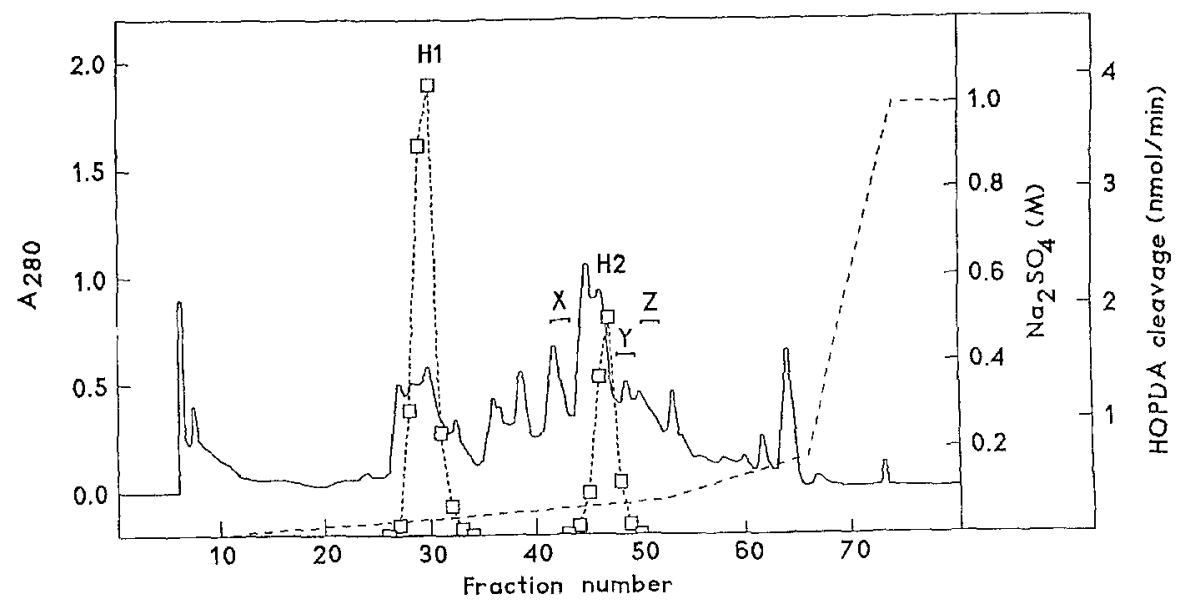

Fig. 2. Separation of two $\mathrm{HO}(\mathrm{H}) \mathrm{PDA}$-hydrolyzing enzymes by anion exchange chromatography. A Mono Q column was equilibrated with buffer A2 (Table 1) at $4 \mathrm{ml} / \mathrm{min}$ and 4-ml fractions were collected. Concentrated eluate (2 ml) from the DEAE column was applied. After 5 min a gradient of buffer B2 was started ( 0 to $8 \%$ buffer B2 over 35 min, 8 to $18 \%$ B2 over 10 min; the flow rate was reduced to $2.5 \mathrm{ml} / \mathrm{min}$ for the latter portions of the gradient, 18 to $100 \% \mathrm{~B} 2$ over $10 \mathrm{~min}$ and $10 \mathrm{~min} 100 \% \mathrm{~B} 2$ ). The bars labelled $\mathrm{X}$, Y and $\mathrm{Z}$ represent THB-1,2-dioxygenase I, catechol 2,3-dioxygenase and THB-1,2-dioxygenase II, respectively. 


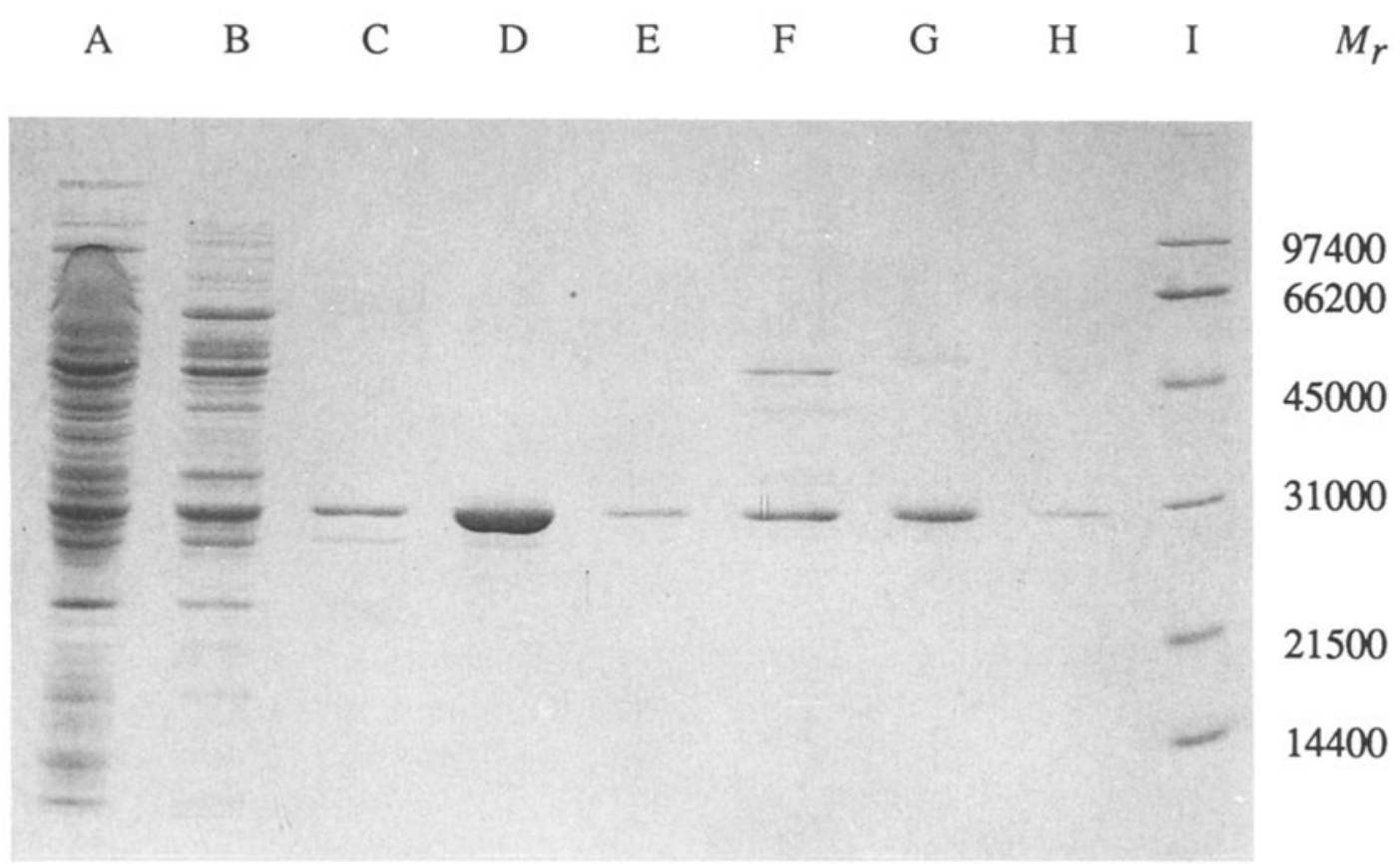

Fig. 3. SDS/PAGE of different steps during the purifications of HOHPDA-hydrolases H1 and H2. Proteins were detected by staining with Coomassie Brilliant Blue R250. Lanes: A, crude extract ( $10 \mu \mathrm{g}$ of protein); B, pooled fractions of both hydrolases eluted from the DEAE column $(6 \mu \mathrm{g})$; C, pooled fractions of hydrolase H1 eluted from the Mono Q column $(1 \mu \mathrm{g})$; D, pooled fractions of hydrolase H1 eluted from the Phenyl Superose column $(2 \mu \mathrm{g})$; E, pooled fractions of hydrolase H1 eluted from the Superose 12 column (1 $\mu \mathrm{g})$; F, pooled fractions of hydrolase $\mathrm{H} 2$ eluted from the Mono $\mathrm{Q}$ column $(2 \mu \mathrm{g}) ; \mathrm{G}$, pooled fractions of hydrolase $\mathrm{H} 2$ eluted from the Phenylsuperose column ( $2 \mu \mathrm{g}$ ); $\mathrm{H}$, pooled fractions of hydrolase $\mathrm{H} 2$ eluted from the Superose 12 column $(1 \mu \mathrm{g}) ; \mathrm{I}$, standard marker proteins (each about $1 \mu \mathrm{g}$ ).

applied to the Phenyl Superose column equilibrated with buffer $\mathrm{A} 3$ and eluted as for $\mathrm{H1}$. Hydrolase $\mathrm{H} 2$ eluted at about $360 \mathrm{mM}\left(\mathrm{NH}_{4}\right)_{2} \mathrm{SO}_{4}$ with the largest of the three protein peaks observed and was concentrated (not shown).

The last step in the purification of each hydrolase was gel filtration (Superose 12) with buffer A4 at a flow rate of $0.4 \mathrm{ml} / \mathrm{min}$ as the mobile phase; fractions of $0.5 \mathrm{ml}$ were collected. Each hydrolase gave a single symmetrical protein peak which co-eluted with the activity peak (not shown). Each pure enzyme was concentrated and stored at $-20^{\circ} \mathrm{C}$ prior to establishing some of its properties.

The effectivity of the different purification steps is illustrated in Fig. 3. Neither hydrolase contains significant impurities after gel filtration.

Purified hydrolases $\mathrm{H} 1$ and $\mathrm{H} 2$ could be stored at $4^{\circ} \mathrm{C}$ for $48 \mathrm{~h}$ with little loss of activity $(10 \% \mathrm{Hl}, 20 \%$ $\mathrm{H} 2$ ). No activity was lost after one week at $-20^{\circ} \mathrm{C}$ or $-70^{\circ} \mathrm{C}$ in buffer containing $30 \%$ glycerol. The

Table 2. Purification of hydrolase $\mathrm{H} 1$

\begin{tabular}{llccccc}
\hline Step & $\begin{array}{l}\text { Volume } \\
(\mathrm{ml})\end{array}$ & $\begin{array}{l}\text { Total protein } \\
(\mathrm{mg})\end{array}$ & $\begin{array}{l}\text { Total activity } \\
(\mathrm{mU})\end{array}$ & $\begin{array}{l}\text { Specific activity } \\
(\mathrm{mU} / \mathrm{mg})\end{array}$ & $\begin{array}{l}\text { Yield } \\
(\%)\end{array}$ & $\begin{array}{l}\text { Purification } \\
(\text { fold })\end{array}$ \\
\hline Crude extract $^{\mathrm{a}}$ & 15 & 375 & 2920 & 7.8 & 100 & 1 \\
DEAE $^{\mathrm{a}}$ & 18 & 69 & 752 & 10.9 & 25.8 & 1.4 \\
Mono Q & 4 & 5 & 533 & 107 & 18.3 & 13.7 \\
Phenyl Superose & 2 & 1.31 & 360 & 274 & 12.3 & 35.3 \\
Superose & 1.5 & 0.8 & 226 & 282 & 7.7 & 36.2 \\
\hline
\end{tabular}

The activity of hydrolase $\mathrm{H} 1$ was measured as HOPDA consumption. Activity of hydrolase H2 was also present. 
Table 3. Purification of hydrolase $\mathrm{H} 2$.

\begin{tabular}{|c|c|c|c|c|c|c|}
\hline Step & $\begin{array}{l}\text { Volume } \\
\text { (ml) }\end{array}$ & $\begin{array}{l}\text { Total protein } \\
(\mathrm{mg})\end{array}$ & $\begin{array}{l}\text { Total activity } \\
(\mathrm{mU})\end{array}$ & $\begin{array}{l}\text { Specific activity } \\
(\mathrm{mU} / \mathrm{mg})\end{array}$ & $\begin{array}{l}\text { Yield } \\
(\%)\end{array}$ & $\begin{array}{l}\text { Purification } \\
\text { (fold) }\end{array}$ \\
\hline Crude extract $^{a}$ & 15 & 375 & 2920 & 7.8 & 100 & 1 \\
\hline DEAE & 18 & 69 & 752 & 10.9 & 25.8 & 1.4 \\
\hline Mono Q & 2.1 & 2.78 & 121 & 43.5 & 4.1 & 5.6 \\
\hline Phenyl Superose & 1.5 & 0.92 & 52 & 56.5 & 1.8 & 7.2 \\
\hline Superose & 1.5 & 0.505 & 31.3 & 61.9 & 1.1 & 7.9 \\
\hline
\end{tabular}

The activity of hydrolase $\mathrm{H} 2$ was measured as HOPDA consumption. ${ }^{a}$ Activity of hydrolase $\mathrm{H} 1$ was also present.

purification procedure for the two hydrolases has been repeated five times and representative purifications are presented (Tables 2 and 3). Typically $15 \mathrm{~g}$ (wet weight) of cells yielded $0.8 \mathrm{mg}$ of pure hydrolase $\mathrm{H} 1$ and $0.5 \mathrm{mg}$ of pure hydrolase $\mathrm{H} 2$.

\section{Detection of two isofunctional THB}

\section{1,2-dioxygenases}

The fractions collected from the DEAE column to purify hydrolases $\mathrm{H} 1$ and $\mathrm{H} 2$ were observed to contain a major portion of an unresolved double peak of THB 1,2-dioxygenase activity. The presence of two isofunctional THB dioxygenases was confirmed on the Mono Q column, where baseline separation was obtained. These dioxygenases eluted at about $50 \mathrm{mM}$ and $75 \mathrm{mM} \mathrm{Na}_{2} \mathrm{SO}_{4}$, straddling, but not significantly overlapping, hydrolase $\mathrm{H} 2$. Fractions of these dioxygenases from either anion exchange column were stable at $-20^{\circ} \mathrm{C}$, but further purification was not attained, because the enzymes rapidly and irreversibly lost activity or were not separated. A catechol-2,3-dioxygenase, which had neither THB nor DHB activity was detected in the eluate from the Mono $Q$ column at $70 \mathrm{mM} \mathrm{Na} 2 \mathrm{SO}_{4}$. No catechol-1,2-dioxygenase activity could be found. THB dioxygenase 1 (Fig. 2) was used to prepare $\mathrm{HO}(\mathrm{H}) \mathrm{PDA}$ (see Methods section).

\section{Some properties of hydrolases $\mathrm{H} 1$ and $\mathrm{H} 2$}

The purified enzymes $\mathrm{H} 1$ and $\mathrm{H} 2$ are HOHPDA hydrolases, because each converted the substrate to salicylate; similarly, each enzyme converted HOP-
DA to benzoate. The reaction products were not formed stoichiometrically. The recoveries of salicylate and benzoate were $66 \%$ and $89 \%$, respectively, with $\mathrm{H} 1$ and $45 \%$ and $75 \%$, respectively, with $\mathrm{H} 2$. Unidentified, but presumably aromatic products were detected by HPLC. We had no satisfactory assay for 2-oxopentenoate.

The hydrolases have very similar $M_{r}$-values, 31 $000(\mathrm{H} 1)$ and $29000(\mathrm{H} 2)$, under denaturing conditions (Fig. 3). $M_{r}$-values for native proteins were estimated by gel filtration (Superose 12 and Superose 6) and native PAGE: 37000,43000 and 40 000, respectively, were obtained for $\mathrm{H} 1$, and 41000,48000 and 45000 , respectively, for $\mathrm{H} 2$. We presume the enzymes to be monomeric.

The amino acid sequence of the N-terminus of hydrolase H1 was:

Thr-Gln-Leu-Pro-Ser-Asn-Phe-Ile-Ala-Thr-XaaGly-Tyr-Arg-Thr-His-Tyr-Ile-Glu-Met

whereas

Met-Phe-Glu-Gln-Phe-Glu-Ser-Lys-Phe-Ile-Asp-

Xaa-Asp-Gly-Ile-Arg-Thr-His-Tyr-Ile

was determined for $\mathrm{H} 2$ and identical amino acids are underlined in the $\mathrm{H} 1$ sequence. There is $50 \%$ identity between the isoenzymes at the N-termini. No similar sequence was found in the SWISSPROT, PIR and MIPSX databases.

\section{Discussion}

HOHPDA hydrolases $\mathrm{H} 1$ and $\mathrm{H} 2$ are similar $\left(M_{r}\right)$ but independent isofunctional enzymes with different properties (separation by ion exchange and hydrophobic interaction; different $\mathrm{N}$-termini). They are representatives of a rare group of hydrolytic en- 
zymes, those which cleave a C-C bond (EC 3.7.1.-). Only ten representatives (including EC 3.7.1.8 and 3.7.1.9), not all of which have been purified, are given in Enzyme Nomenclature 1992 (Webb 1992). One keto group and another labile bond are essential to facilitate the reaction and Omori et al. (1986a) present a reasonable reaction scheme for EC 3.7.1.8. Omori et al. (1986a) identified the nature of the C5 moiety cleaved from HOPDA as 2oxopent-4-enoate, and Strubel et al. (1991) were able to detect the oxopentenoate from $\mathrm{HO}(\mathrm{H}) \mathrm{PDA}$ with partially purified enzymes. We thus presume that hydrolases $\mathrm{H} 1$ and $\mathrm{H} 2$ also release the $\mathrm{C5}$ moiety as the oxopentenoate (and correspondingly that the hydrolases can be ascribed to EC 3.7.1.8), but this has yet to be confirmed in strain RW1. The reactivity of HOPDA, and more especially of HOHPDA, has the consequence that spontaneous reactions occur independent of the enzymic reaction. This has the consequence that the enzymic reaction apparently does not proceed stoichiometrically. This effect is thus not limited to enzyme reactions in vitro: Fortnagel et al. (1990), Strubel et al. (1991), Wittich et al. (1992) and Kohler et al. (1993) report the formation of chromanone derivatives from HOHPDA via a spontaneous intramolecular Michael addition in growing cells. So complete turnover of substrate does not mean complete mineralization of the compound.

The HOPDA hydrolase isolated by Omori et al. (1986a) is a homomultimer, possibly a hexamer $\left(M_{r}\right.$ 160000 ) of subunit $M_{r} 29000$. The 2-hydroxy-6oxo-2,4-heptadienoate hydrolases from Bayly \& Di Berardino (1978) appear to be homotetramers $\left(M_{r}\right.$ 118000 and 100000 ), with subunits of $M_{r} 28000$ and $M_{r} 25000$, respectively, whereas the hydrolase described by Duggleby \& Williams (1986), encoded on a TOL plasmid, is a homodimer $\left(M_{r} 65000\right)$ with subunits of $M_{r}$ about 32000 . Duggleby \& Williams (1986) discuss the differences between these three hydrolases (EC 3.7.1.9) as well as the degrees of immunological relatedness. The enzymes we isolated have essentially the same $M_{r}$ under denaturing conditions as those cited in EC 3.7.1.8 and EC 3.7.1.9, but we believe the enzymes from Sphingomonas to be monomeric. We have no other means of comparing our enzymes with those in EC 3.7.1.8 and EC
3.7.1.9, apart from the absence of cofactors in each case, and a search in a sequence database gave no related proteins. This will presumably reflect the low number of enzymes in EC 3.7.1.- and the difficulty of working biochemically or genetically with an enzyme whose labile substrate has to be synthesized enzymically.

In contrast to the failure to find in the database any proteins related to the HOHPDA hydrolases from Sphingomonas sp. strain RW1, the isoenzymes $\mathrm{H} 1$ and $\mathrm{H} 2$ share $50 \%$ sequence homology at the $\mathrm{N}$-terminus. These enzymes are produced essentially constitutively, as are the two THB dioxygenases (see above) and two reductases for the dibenzofuran dioxygenase system (Bünz \& Cook 1993). The reason for this is open to conjecture, but possibly expression of not one but two similar degradative pathways is constitutive. The other could be a portion of a biphenyl degradative pathway, because biphenyl-utilizing mutants of this organism occur spontaneously (Wittich et al. 1992).

\section{Acknowledgements}

We are grateful to Prof. T. Leisinger for making available laboratory space and apparatus, to Prof. $P$. Fortnagel for making the project available, and to Dr. H.H. Locher and Mr. H.R. Schläfli for advice on protein purification.

This work was supported by a grant from the Claussen-Stiftung im Stifterverband für die Deutsche Wissenschaft and by the Swiss Federal Institute of Technology, Zürich.

\section{References}

Ahmad D, Sylvestre M, Sondossi M \& Massé R (1991) Bioconversion of 2-hydroxy-6-oxo-6-(4'-chlorophenyl)hexa-2,4-dienoic acid, the meta-cleavage product of 4-chlorobiphenyl. J. Gen. Microbiol. 137: 1375-1385

Bayly RC \& Di Berardino D (1978) Purification and properties of 2-hydroxy-6-oxo-2,4-heptadienoate hydrolase from two strains of Pseudomonas putida. J. Bacteriol. 134: 30-37

Bird JA \& Cain RB (1974) Microbial degradation of alkylbenzenesulfonates: metabolism of homologues of short alkylchain length by an Alcaligenes sp. Biochem. J. 140: 121-134 
Bradford MM (1976) A rapid and sensitive method for the quantitation of microgram quantities of protein utilizing the principle of protein-dye binding. Anal. Biochem. 72: 248-254

Bünz PV \& Cook AM (1993) Dibenzofuran 4,4a-dioxygenase from Sphingomonas sp. strain RW1: angular dioxygenation by a three-component enzyme system. J. Bacteriol. In Press

Correll CC, Batie CJ, Ballou DP \& Ludwig ML (1992) Phthalate dioxygenase reductase: a modular structure for electron transfer from pyridine nucleotides to [2Fe-2S]. Science 258: 16041610

Drews G (1983) Mikrobiologisches Praktikum, 4th ed. Springer Berlin

Duggleby CJ \& Williams PA (1986) Purification and some properties of the 2-hydroxy-6-oxahepta-2,4-dienoate hydrolase (2hydroxymuconate semialdehyde hydrolase) encoded by the TOL plasmid pWW0 from Pseudomonas putida mt2. J. Gen. Microbiol. 132: 717-726

Engesser KH, Strubel V, Christoglou K, Fischer P \& Rast HG (1989) Dioxygenolytic cleavage of aryl ether bonds: 1,10-dihydro-1,10-dihydroxyfluoren-9-one, a novel arene dihydrodiol as evidence for angular dioxygenation of dibenzofuran. FEMS Microbiol. Lett. 65 : 205-210

Fortnagel P, Harms H, Wittich R-M, Francke W, Krohn S \& Meyer H (1989) Cleavage of dibenzofuran and dibenzodioxin ring systems by a Pseudomonas bacterium. Naturwissenschaften 76:222-223

Fortnagel P, Harms H, Wittich R-M, Krohn S, Meyer H, Sinnwell V, Wilkes H \& Francke W (1990) Metabolism of dibenzofuran by Pseudomonas sp. HH69 and the mixed culture $\mathrm{HH} 27$. Appl. Environ. Microbiol. 56: 1148-1156

Gibson DT, Roberts RL, Wells MC \& Kobal VM (1973) Oxidation of biphenyl by a Beijerinkia species. Biochem. Biophys. Res. Commun. 50: 211-219

Haddock JD, Nadim LM \& Gibson DT (1993) Oxidation of biphenyl by a multicomponent enzyme system from Pseudomonas sp. strain LB400. J. Bacteriol. 175: $395-400$

Harayama S, Kok M \& Neidle EL (1992) Functional and evolutionary relationships among diverse oxygenases. Annu. Rev. Microbiol. 46: 565-601

Higson FK (1992) Microbial degradation of biphenyl and its derivatives. Adv. Appl. Microbiol. 37: 135-164

Ishigooka H, Yoshida Y, Omori T \& Minoda Y (1986) Enzymatic dioxygenation of biphenyl-2,3-diol and 3-isopropylcatechol. Agric. Biol. Chem. 50: 1045-1046

Kohler H-PE, Schmid A \& van der Maarel M (1993) Metabolism of 2,2'-dihydroxybiphenyl by Pseudomonas sp. strain HPB1: production and consumption of 2,2',3-trihydroxybiphenyl. $\mathbf{J}$. Bacteriol. 175: 1621-1628
Laemmli UK (1970) Cleavage of structural proteins during the assemble of the head of bacteriophage T4. Nature (London) 227: 680-685

Lipscomb JD, Whittaker JW, Arciero DM, Orville AM \& Wolgel SA (1988) Mechanisms of catecholic dioxygenases. In: Hagedorn SR, Hanson RS \& Kunz DA (Eds) Microbial Metabolism and the Carbon Cycle (pp 259-281). Harwood, Chur

Locher HH, Leisinger T \& Cook AM (1989) Degradation of $p$ toluenesulphonic acid via sidechain oxidation, desulphonation and meta ring cleavage in Pseudomonas (Comamonas) testosteroni T-2. J. Gen. Microbiol. 135: 1969-1978

-(1991) 4-Sulphobenzoate 3,4-dioxygenase: purification and properties of a desulphonative two-component enzyme system from Comamonas testosteroni T-2. Biochem. J. 274: 833842

Mason JR \& Cammack R (1992) The electron-transport proteins of hydroxylating bacterial dioxygenases. Annu. Rev. Microbiol. 46: 277-305

Merril CR, Goldman D \& Van Keuren ML (1983) Silver staining methods for polyacrylamide gel electrophoresis. Methods Enzymol. 96: 230-239

Omori T, Sugimura K, Ishigooka H \& Minoda Y (1986a) Purification and some properties of a 2-hydroxy-6-oxo-6-phenylhexa-2,4-dienoic acid hydrolyzing enzyme from Pseudomonas cruciviae S93B1 involved in the degradation of biphenyl. Agric. Biol. Chem. 50: 931-937

Omori T, Ishigooka H \& Minoda Y (1986b) Purification and some properties of 2-hydroxy-6-oxo-6-phenylhexa-2,4-dienoic acid (HOPDA) reducing enzyme from Pseudomonas cruciviae S93 B1 involved in the degradation of biphenyl. Agric. Biol. Chem. 50: 1513-1518

Strubel V, Engesser K-H, Fischer P \& Knackmuss H-J (1991) 3(2-Hydroxyphenyl)catechol as substrate for proximal meta cleavage in dibenzofuran degradation by Brevibacterium sp. strain DPO 1361. J. Bacteriol. 173: 1932-1937

Webb EC (1992) Enzyme nomenclature 1992. Academic Press, San Diego

Whitman CP, Aird BA, Gillespie WR \& Stolowich NJ (1991) Chemical and enzymatic ketonization of 2-hydroxymuconate, a conjugated enol. J. Amer. Chem. Soc. 113: 3154-3162

Wilkes H, Francke W, Wittich R-M, Harms H, Schmidt S \& Fortnagel $P$ (1992) Mechanistic investigations on microbial degradation of diaryl ethers: analysis of isotope labeled reaction products. Naturwissenschaften 79: 269-271

Wittich R-M, Wilkes H, Sinnwell V, Francke W \& Fortnagel P (1992) Metabolism of dibenzo-p-dioxin by Sphingomonas sp. strain RW1. Appl. Environ. Microbiol. 58: 1005-1010 